Article

\title{
Lipase-Catalyzed Kinetic Resolution of Aryltrimethylsilyl Chiral Alcohols
}

\section{Dayvson J. Palmeira, Juliana C. Abreu and Leandro H. Andrade *}

Institute of Chemistry, University of São Paulo, Av. Prof. Lineu Prestes, nº. 748, SP 05508-900, São Paulo, Brazil; E-Mails: dayvson.palmeira@gmail.com (D.J.P.); jukinhabreu@hotmail.com (J.C.A.)

* Author to whom correspondence should be addressed; E-Mail: leandroh@iq.usp.br;

Tel.: +55-11-3091-2287.

Received: 27 September 2011; in revised form: 28 October 2011 / Accepted: 17 November 2011 / Published: 23 November 2011

\begin{abstract}
Lipase-catalyzed kinetic resolution of aryltrimethylsilyl chiral alcohols through a transesterification reaction was studied. The optimal conditions found for the kinetic resolution of $m$ - and $p$-aryltrimethylsilyl chiral alcohols, led to excellent results, high conversions $(c=50 \%)$, high enantiomeric ratios $(E>200)$ and enantiomeric excesses for the remaining $(S)$-alcohol and $(R)$-acetylated product $(>99 \%)$. However, kinetic resolution of $o$-aryltrimethylsilyl chiral alcohols did not occur under the same conditions applied to the other isomers.
\end{abstract}

Keywords: lipase; aryltrimethylsilyl chiral alcohols; kinetic resolution; transesterification

\section{Introduction}

The chemistry of organosilicon compounds is well-established nowadays due to its importance in organic synthesis, in which these compounds can be used for carbon-carbon bond formation as well as protecting-group reagents [1,2]. In addition, most of the organosilicon compounds are generally easy to handle and store. They are thermal stable and present low toxicity [3,4]. These characteristics make the organosilicon compounds a good choice for diverse organic synthesis methodologies. Aryltrimethylsilyl compounds have attracted special attention because they are involved in some interesting desilylative functionalizations, such as aryne formation [5-10], oxyarylation of alkenes [11,12], phosphazene base-promoted functionalization [13], metal-catalyzed cross-coupling reactions [14-18] and palladium-catalyzed oxidative coupling reaction [19]. 
Although silicon-containing organic compounds find a remarkable application in organic synthesis, there is a general lack of biocatalyzed studies using these compounds as substrates, and only a few such biocatalyzed transformations of organosilanes have been reported, such as the stereoselective microbial reduction of racemic acetyl(t-butyl)methylphenyl silane [20], preparation of $p$-(trimethylsilyl)phenylalanine through an amidohydrolase produced by a bacterium [21], enantioselective microbial reduction of acyl silanes [22], the synthesis of $(R)$-2-trimethylsilyl-2-hydroxyethylcyanide by a $(R)$-oxynitrilase-catalyzed hydrogen cyanide addition [23], biocatalytic cleavage of silicon-oxygen bonds [24,25] and enzyme-catalyzed siloxane bond formation [26-28]. Reports on lipase-catalyzed kinetic resolution of organosilanes are even scarcer. To our knowledge, just a few publications have focused on this type of biocatalytic reaction, such as the synthesis of optically active 2-sila-1,3propanediols through a regioselective transesterification reaction catalyzed by a series of lipases [29], the preparation of optically active silylmethanol derivatives through lipase-catalyzed enantioselective esterification and transesterification [30], enantioselective transesterification of 1-trimethylsilyl-1-alkyn3-ols catalyzed by immobilized Pseudomonas cepacia lipase PS and Pseudomonas fluorescens [31-33], and the kinetic resolution of 4-(phenyldimethylsilyl)-3-butyn-2-ol for the preparation of enantioenriched allenylsilanes [34]. However, there are no reports in the literature, in which aryltrimethylsilyl compounds have been used in lipase-catalyzed kinetic resolution. The aim of this work was therefore to carry out an extensive study on the lipase-catalyzed kinetic resolution of aryltrimethylsilyl chiral alcohols via transesterification reaction.

\section{Results and Discussion}

\subsection{Synthesis of Aryltrimethylsilyl Chiral Alcohols 2a-f}

1-(Bromo-phenyl)ethanols 1a-f were synthesized in excellent yields (90-92\%) by reacting $o-, m-$, and $p$-bromo-substituted acetophenones with $\mathrm{NaBH}_{4}$ (Scheme 1) [35].

Scheme 1. Reduction of bromo-substituted acetophenones to afford chiral alcohols 1a-c.

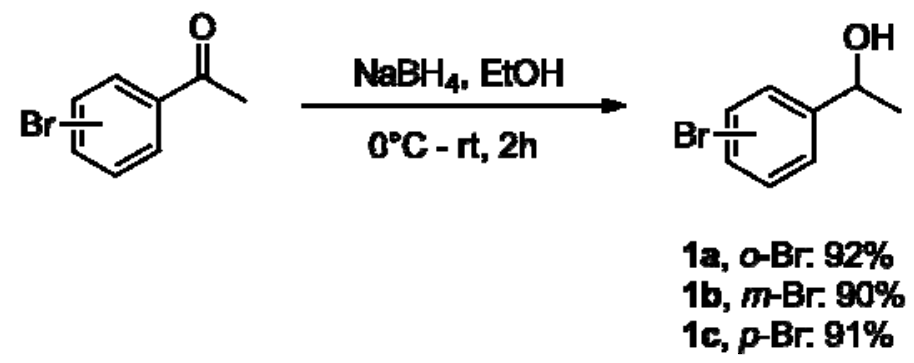

The addition of a Grignard reagent to the $o_{-}^{-}, m-$, and $p$-bromo-substituted benzaldehydes gave the chiral alcohols 1d-f bearing an ethyl group attached at the benzylic carbon, in good yields (70\%-87\%, Scheme 2). 
Scheme 2. Carbonyl addition of a Grignard reagent to bromo-substituted benzaldehydes to give chiral alcohols 1d-f.

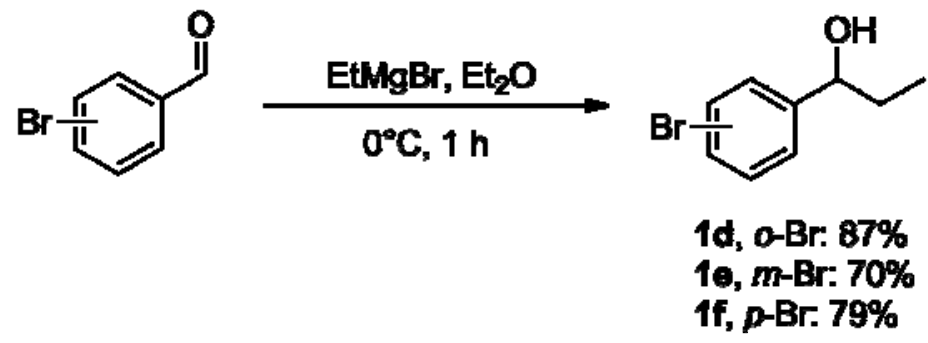

With the aryl bromides precursors 1a-f in hand, we next synthesized aryltrimethylsilyl chiral alcohols. The compounds 1a-f were submitted to the bromo-lithium exchange reaction with $n$-butyllithium, THF at $-70{ }^{\circ} \mathrm{C}$, followed by addition of trimethylsilyl chloride. The disilylated intermediates were generated in situ, and after acid hydrolysis reaction, aryltrimethylsilyl chiral alcohols 2a-f were obtained in moderate to good yields $(62 \%-76 \%$, Scheme 3$)$.

Scheme 3. Synthesis of the aryltrimethylsilyl chiral alcohols $\mathbf{2 a}-\mathbf{f}$.
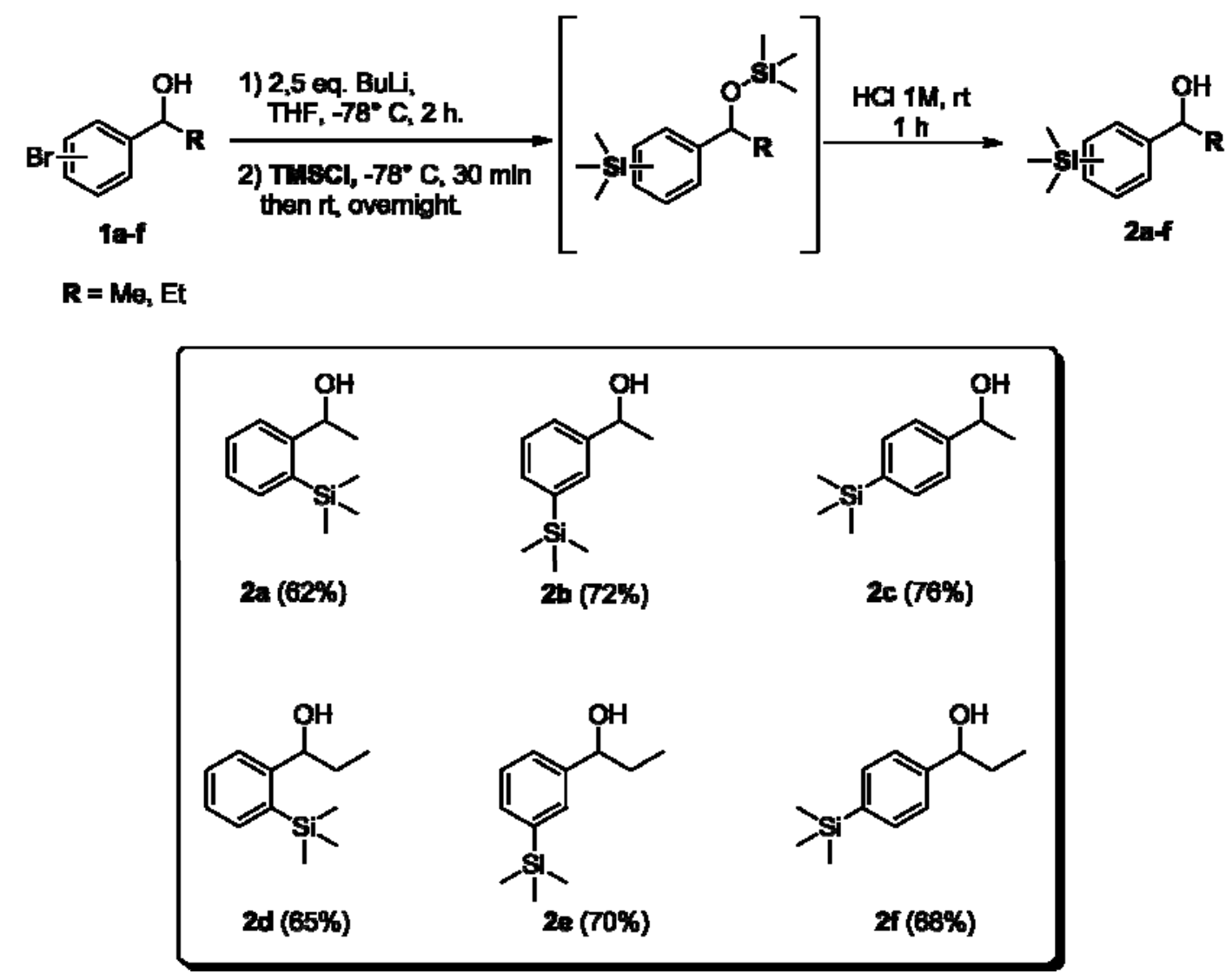

\subsection{Enzymatic Kinetic Resolution of the Aryltrimethylsilyl Chiral Alcohols 2a-f}

Initially, we focused our study on choosing the best lipase source for the enzymatic kinetic resolution (EKR) of aryltrimethylsilyl chiral alcohols through transesterification reaction. For the lipase screening, vinyl acetate was chosen as the acyl donor, hexane as the solvent, and the compound 
$(R S)$-2c as the model substrate. Eleven types of lipase sources were used in the kinetic resolution of compound $(R S)$-2c. The results are summarized in Table 1.

Table 1. Screening of lipases for the kinetic resolution of $(R S)-2 \mathbf{c}^{\text {a }}$.

\begin{tabular}{|c|c|c|c|c|c|}
\hline & 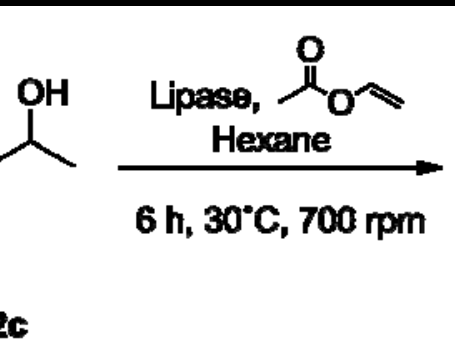 & $(S)-2 c$ & & $(R)$ & \\
\hline \multirow{2}{*}{ Entry } & \multirow{2}{*}{ Lipase (source) } & \multicolumn{2}{|c|}{$e e(\%)^{b}$} & \multirow{2}{*}{$c(\%)^{c}$} & \multirow{2}{*}{$E^{d}$} \\
\hline & & $(S)-2 \mathrm{c}$ & $(R)-3 c$ & & \\
\hline 1 & $\begin{array}{c}\text { Mucor javanicus } \\
\text { (Amano } \mathrm{M})\end{array}$ & - & - & - & - \\
\hline 2 & $\begin{array}{c}\text { Candida cylindracea } \\
\text { (Fluka) }\end{array}$ & - & - & - & - \\
\hline 3 & $\begin{array}{c}\text { Candida antarctica } \\
\text { (CAL-B, Novozym 435) }\end{array}$ & 74 & $>99$ & 43 & $>200$ \\
\hline 4 & $\begin{array}{c}\text { Pseudomonas cepacia } \\
\text { (Amano PS) }\end{array}$ & 48 & $>99$ & 33 & $>200$ \\
\hline 5 & $\begin{array}{c}\text { Aspergillus niger } \\
\text { (Amano A) }\end{array}$ & - & - & - & - \\
\hline 6 & $\begin{array}{l}\text { Pseudomonas cepacia } \\
\text { (Amano PS-D I) }\end{array}$ & 98 & $>99$ & 49 & $>200$ \\
\hline 7 & $\begin{array}{c}\text { Candida rugosa } \\
\text { (Amano, type VII) }\end{array}$ & - & - & - & - \\
\hline 8 & $\begin{array}{l}\text { Pseudomonas cepacia } \\
\text { (Amano PS-C II) }\end{array}$ & $>99$ & $>99$ & 50 & $>200$ \\
\hline 9 & $\begin{array}{c}\text { Mucor meihei } \\
\text { (Sigma) }\end{array}$ & - & - & - & - \\
\hline 10 & $\begin{array}{c}\text { Pseudomonas fluorescens } \\
\text { (Amano AK) }\end{array}$ & 58 & $>99$ & 37 & $>200$ \\
\hline 11 & $\begin{array}{c}\text { Porcine pancreas } \\
\text { (Sigma, type II) }\end{array}$ & - & - & - & - \\
\hline
\end{tabular}

${ }^{a}$ General conditions: Substrate (0.05 mmol), lipase (2 mg), vinyl acetate $(0.11 \mathrm{mmol})$, hexane $(200 \mu \mathrm{L})$;

${ }^{\mathrm{b}}$ Determined by chiral GC analysis; ${ }^{\mathrm{c}}$ Conversion: $c=e e_{\mathrm{S}} /\left(e e_{\mathrm{S}}+e e_{\mathrm{P}}\right) ;{ }^{\mathrm{d}} E=\ln \left\{\left[e e_{\mathrm{P}}\left(1-e e_{\mathrm{S}}\right) /\left(e e_{\mathrm{P}}+\right.\right.\right.$ $\left.\left.\left.e e_{\mathrm{S}}\right)\right]\right\} / \ln \left\{\left[e e_{\mathrm{P}}\left(1+e e_{\mathrm{S}}\right) /\left(e e_{\mathrm{P}}+e e_{\mathrm{S}}\right)\right]\right\} ;(-)=$ No reaction.

Lipases from Mucor javanicus, Candida cylindracea, Aspergillus niger, Candida rugosa, Mucor meihei and porcine pancreas (Table 1, entries 1, 2, 5, 7, 9 and 11) showed no activity for the transesterification reaction of $(R S)$-2c, and only unreacted racemic alcohol was recovered at the end of the process. On the other hand, high enantiomeric ratios $(E>200)$ and excellent enantiomeric excess for $(R)$-3c (ee $>99 \%$ ) were achieved when lipases from Candida antarctica (CAL-B), Pseudomonas cepacia [free form (Amano PS), immobilized on diatomite (Amano PS-DI) or immobilized on ceramic (Amano PS-CII)] and Pseudomonas fluorescens (entries 3, 4, 6, 8 and 10) were used as biocatalysts. 
When Pseudomonas cepacia immobilized on diatomite (Amano PS-DI) or ceramic (Amano PS-CII) (entries 6 and 8) were used, high conversions were obtained (49\% and 50\%, respectively). Based on these results and aiming future application in the chemoenzymatic dynamic resolution of aryltrimethylsilyl chiral alcohols, the lipase from Pseudomonas cepacia Amano PS-C II (Table 1, entry 8) was chosen for the subsequent studies. The amount of enzyme and reaction time were also evaluated in order to achieve the perfect kinetic resolution process (Table 2).

Table 2. Evaluation of reaction time and enzyme/substrate ratio for kinetic resolution of $(R S)-\mathbf{2 c}{ }^{\mathrm{a}}$.

\begin{tabular}{|c|c|c|c|c|c|c|c|}
\hline \multirow{2}{*}{ Entry } & \multirow{2}{*}{$\begin{array}{c}\text { Substrate } \\
(\mathbf{m m o l})\end{array}$} & \multirow{2}{*}{$\begin{array}{c}\text { Amano PS-C II } \\
(\mathrm{mg})\end{array}$} & \multirow{2}{*}{$\begin{array}{c}\text { Time } \\
\text { (h) }\end{array}$} & \multicolumn{2}{|c|}{$e e(\%)^{b}$} & \multirow{2}{*}{$c(\%)^{c}$} & \multirow{2}{*}{$E^{d}$} \\
\hline & & & & $(S)-2 \mathrm{c}$ & $(R)-3 \mathbf{c}$ & & \\
\hline 1 & 0.05 & 2 & 6 & $>99$ & $>99$ & 50 & $>200$ \\
\hline 2 & 0.05 & 2 & 3 & $>99$ & $>99$ & 50 & $>200$ \\
\hline 3 & 0.05 & 1 & 6 & $>99$ & $>99$ & 50 & $>200$ \\
\hline 4 & 0.05 & 1 & 3 & $>99$ & $>99$ & 50 & $>200$ \\
\hline 5 & 0.05 & 1 & 1.5 & 86 & $>99$ & 46 & $>200$ \\
\hline 6 & 0.1 & 1 & 6 & $>99$ & $>99$ & 50 & $>200$ \\
\hline 7 & 0.1 & 1 & 3 & 83 & $>99$ & 45 & $>200$ \\
\hline 8 & 0.1 & 1 & 1.5 & 48 & $>99$ & 33 & $>200$ \\
\hline
\end{tabular}

${ }^{\mathrm{a}}$ General conditions: vinyl acetate $(2.2$ equiv. $)$, hexane $(200 \mu \mathrm{L}) ;{ }^{\mathrm{b}}$ Determined by chiral GC analysis; ${ }^{\mathrm{c}}$ Conversion: $c=e e_{\mathrm{S}} /\left(e e_{\mathrm{S}}+e e_{\mathrm{P}}\right) ;{ }^{\mathrm{d}} E=\ln \left\{\left[e e_{\mathrm{P}}\left(1-e e_{\mathrm{S}}\right) /\left(e e_{\mathrm{P}}+e e_{\mathrm{S}}\right)\right]\right\} / \ln \left\{\left[e e_{\mathrm{P}}\left(1+e e_{\mathrm{S}}\right) /\left(e e_{\mathrm{P}}\right.\right.\right.$ $\left.\left.\left.+e e_{\mathrm{S}}\right)\right]\right\}$.

After 6 hours reaction, a decrease in the enzyme amount and an increase in substrate quantities (entries 1, 3 and 6) led to perfect kinetic resolution of (RS)-2c. However, excellent results were also achieved after 3 hours (entries 2 and 4), even with a decrease in enzyme concentration (entry 4). Maintaining the reaction time $(3 \mathrm{~h}), 1 \mathrm{mg}$ of enzyme, but increasing the amount of substrate (entry 7), a small decrease in conversion was observed. Reactions performed in $1.5 \mathrm{~h}$ (entries 5 and 8) presented the lowest conversions, indicating that the kinetic resolution of $(R S)-2 \mathrm{c}$ did not occur completely.

Thus, the optimized conditions, considering reaction time and amount of substrate and enzyme (entry 4), was then applied to enzymatic kinetic resolution of several aryltrimethylsilyl chiral alcohols 2a,b,d,e,f (Table 3).

The EKR of compounds $(R, S)$-2b,f (Table 3, entries 3 and 9, respectively) performed in $3 \mathrm{~h}$ led to very good results with high conversions ( $47 \%$ and $49 \%$, respectively) and excellent enantioselectivity ( $E>200$ in both cases). We extended the reaction time to $16 \mathrm{~h}$ (Table 3, entries 4 and 10), and a perfect kinetic resolution of $(R, S)-\mathbf{2 b}, \mathbf{f}$ was achieved (conversion of $50 \%$ and enantiomeric excesses for $(S)-2$ and $(R)-3>99 \%$, in both cases). In regards to compound $(R, S)-2 \mathbf{e}$, a three-hour reaction (Table 3, entry 7) led to low conversion $(c=35 \%)$. Only when the reaction time and enzyme amount were increased to $24 \mathrm{~h}$ and $2 \mathrm{mg}$, respectively (Table 3, entry 8), excellent conversion ( $c=50 \%$ ), enantioselectivity $(E>200)$ and enantiomeric excesses $(e e>99 \%$ for both $(S)$-2e and $(R)$-3e) were found. 
Table 3. Enzymatic kinetic resolution of aryltrimethylsilyl chiral alcohols $\mathbf{2 a}, \mathbf{b}, \mathbf{d}, \mathbf{e}, \mathbf{f}^{\text {a }}$.

\begin{tabular}{|c|c|c|c|c|c|c|}
\hline \multirow{2}{*}{ Entry } & \multirow{2}{*}{ Substrate } & \multirow{2}{*}{ Time (h) } & \multicolumn{2}{|c|}{$e e(\%)^{b}$} & \multirow{2}{*}{$c(\%)^{c}$} & \multirow{2}{*}{$E^{d}$} \\
\hline & & & $(S)-2$ & $(R)-3$ & & \\
\hline 1 & $(R S)-\mathbf{2 a}$ & 3 & - & - & - & - \\
\hline 2 & $(R S)-\mathbf{2 a}$ & 16 & - & - & - & - \\
\hline 3 & $(R S)-\mathbf{2} \mathbf{b}$ & 3 & 87 & $>99$ & 47 & $>200$ \\
\hline 4 & $(R S)-\mathbf{2} \mathbf{b}$ & 16 & $>99$ & $>99$ & 50 & $>200$ \\
\hline 5 & $(R S)-\mathbf{2 d}$ & 3 & - & - & - & - \\
\hline 6 & $(R S)-\mathbf{2 d}$ & 16 & - & - & - & - \\
\hline 7 & $(R S)-\mathbf{2 e}$ & 3 & 54 & $>99$ & 35 & $>200$ \\
\hline 8 & $(R S)-2 \mathbf{e}^{\mathrm{e}}$ & 24 & $>99$ & $>99$ & 50 & $>200$ \\
\hline 9 & $(R S)-\mathbf{2 f}$ & 3 & 96 & $>99$ & 49 & $>200$ \\
\hline 10 & $(R S)-2 \mathbf{f}$ & 16 & $>99$ & $>99$ & 50 & $>200$ \\
\hline
\end{tabular}

${ }^{\text {a }}$ General conditions: substrate $(0.05 \mathrm{mmol})$, enzyme $(1 \mathrm{mg})$, vinyl acetate $(0.11 \mathrm{mmol})$, hexane $(200 \mu \mathrm{L}) ;{ }^{\mathrm{b}}$ Determined by chiral GC analysis; ${ }^{\mathrm{c}}$ Conversion: $c=e e_{\mathrm{S}} /\left(e e_{\mathrm{S}}+e e_{\mathrm{P}}\right) ;{ }^{\mathrm{d}} E=\ln \left\{\left[e e_{\mathrm{P}}(1-\right.\right.$ $\left.\left.\left.e e_{\mathrm{S}}\right) /\left(e e_{\mathrm{P}}+e e_{\mathrm{S}}\right)\right]\right\} / \ln \left\{\left[e e_{\mathrm{P}}\left(1+e e_{\mathrm{S}}\right) /\left(e e_{\mathrm{P}}+e e_{\mathrm{S}}\right)\right]\right\} ;{ }^{\mathrm{e}}$ Amount of enzyme: $2 \mathrm{mg} ;(-)=$ No reaction.

As it can be seen, after three-hour reaction, $p$-trimethylsilyl-substituted phenyl chiral alcohols 2c,f (Table 2, entry 4 and table 3, entry 9) showed better conversion than $m$-trimethylsilyl substituted analogues $\mathbf{2 b}$,e (Table 3, entries 3 and 7). The size of the alkyl chain (methyl: $\mathbf{2 b}$, ethyl: $\mathbf{2 e}$ ) attached to the chiral carbon has a small influence in the conversion of alcohols $\mathbf{2 b}, \mathbf{e}$ into esters $\mathbf{3 b}, \mathbf{e}$. For example, the enzymatic kinetic resolution of alcohol $\mathbf{2 b}$ presented $47 \%$ conversion whereas for the alcohol $\mathbf{2 e}$ presented 35\% (Table 3, entries 3 and 7). Nevertheless, in all cases excellent enantioselectivities were achieved.

Lipase-catalyzed transesterification of $o$-trimethylsilyl substituted phenyl chiral alcohols $(R S)$-2a,d did not occur neither after $3 \mathrm{~h}$ (entries 1 and 5) nor $16 \mathrm{~h}$ (entries 2 and 6). To overcome this obstacle, attempts towards the enantioselective hydrolysis of (RS)-3a,d were made (Scheme 4) [36].

Scheme 4. Attempts towards the enantioselective hydrolysis of $(R S)$-3a,d.<smiles>[R]C(OC(C)=O)c1ccccc1[Si](C)(C)C</smiles>

$(R, S)-3 a, d$

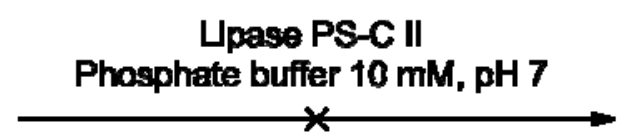

$30^{\circ} \mathrm{C}, 700$ rpm, $24 \mathrm{~h}$

$$
\mathbf{R}=\mathbf{M e}, \mathbf{E} \mathbf{t}
$$

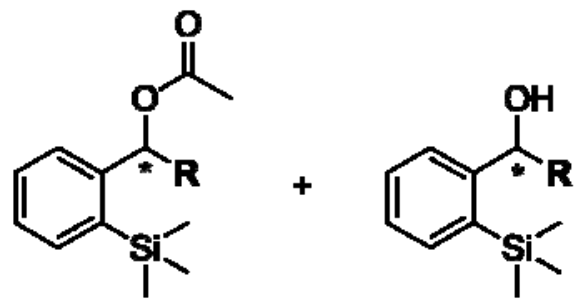

$(R, S)-3 a, d$
$(R, S)-2 a, d$

However, by using PS-C II lipase, phosphate buffer solution (10 mM, pH 7) and ester (RS)-3a,d as substrate, no hydrolysis products (2a,d) were obtained. A possible explanation for these results may involve a non-bonded $\mathrm{Si} \cdots \mathrm{O}$ attraction by pseudo-pentacoordinated species (Figure 1). 
Figure 1. Possible pseudo-pentacoordinated species that can be present on the active site of the enzyme.

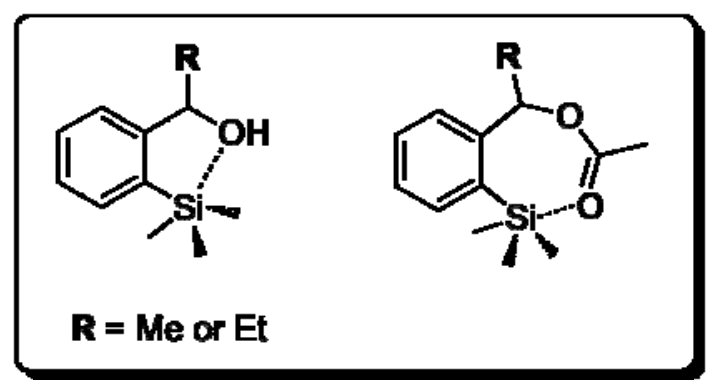

Pseudo-pentacoordinated species have been evidenced in studies involving silyl formates [37], di- and trisilanes bearing the (dimethylamino)-1-naphthyl group [38,39], $N$-substituted trimethylsilyl carbamates [40] and $\mathrm{N}$-trimethylsilylated cyclic ureas [41]. Assuming the five- and seven-membered pseudo-rings formed from this intramolecular interaction, a steric hindrance, due to a rigid array of these structures, could be unfavorable for the formation of enzyme-substrate complexes.

This proposal is endorsed by the results obtained for the $m$ - and $p$-trimethylsilyl substituted phenyl chiral alcohols, in which the non-bonded $\mathrm{Si}{ }^{\prime} \mathrm{O}$ attraction should be less intense and pseudo-pentacoordinated species can hardly be formed. In these cases the kinetic resolution proceed as expected. Motivated by the excellent results, we decided to carry out the enzymatic kinetic resolution of $(R, S)-\mathbf{2 b}, \mathbf{c}$ and $(R, S)-\mathbf{2 e}, \mathbf{f}$ on a higher scale (Table 4$)$.

Table 4. Lipase-catalyzed kinetic resolution of compounds $(R, S)-\mathbf{2 b}, \mathbf{c}$ and $(R, S)-\mathbf{2} \mathbf{e}, \mathbf{f}$ a

Entry Substrate


Table 4. Cont.

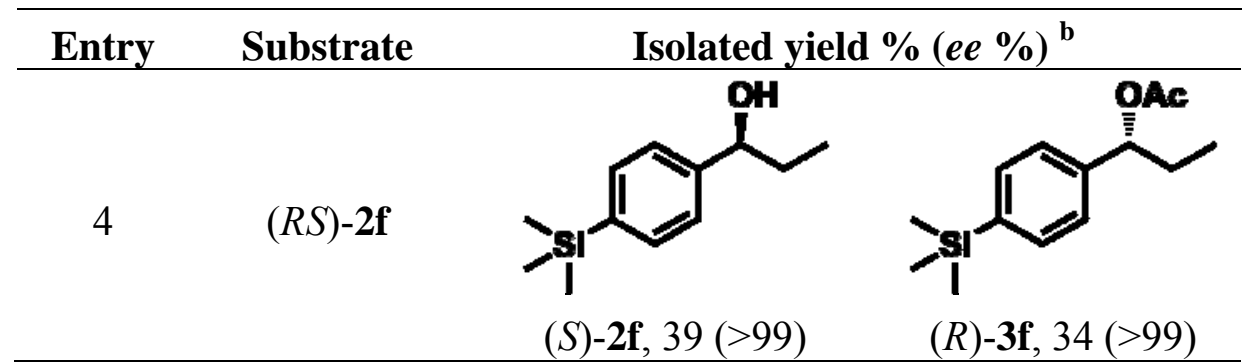

${ }^{a}$ General conditions: substrate $(1 \mathrm{mmol})$, enzyme $(20 \mathrm{mg})$, vinyl acetate $(2.2 \mathrm{mmol}, 203 \mu \mathrm{L})$, hexane $(4 \mathrm{~mL})$, reaction time of $16 \mathrm{~h} ;{ }^{b}$ Determined by chiral GC analysis; ${ }^{\mathrm{c}}$ Reaction time of $3 \mathrm{~h}$;

${ }^{\mathrm{d}}$ Reaction time of $24 \mathrm{~h}$ and amount of enzyme $=40 \mathrm{mg}$.

According to the results on Table 4, the lipase-catalyzed kinetic resolution of $(R, S)-\mathbf{2} \mathbf{b}, \mathbf{c}$ and $(R, S)-2 \mathbf{e}, \mathbf{f}$ led to excellent results with enantiomeric excesses $>99 \%$ in all cases and isolated yields of up to $49 \%$.

\subsection{Determination of Absolute Configuration of Enantioenriched Aryltrimethylsilyl Chiral Alcohols}

(2b, 2c, 2e and 2f)

The enantioenriched compounds $\mathbf{2 b}, \mathbf{2 c}, \mathbf{2} \mathbf{e}$ and $\mathbf{2 f}$ were submitted to a bromodesilylation reaction in order to obtain the corresponding bromides (Scheme 5).

Figure 5. Bromodesilylation of enantioenriched compounds $\mathbf{2 b}, \mathbf{2 c}, \mathbf{2 e}$ and $2 \mathbf{f}$.

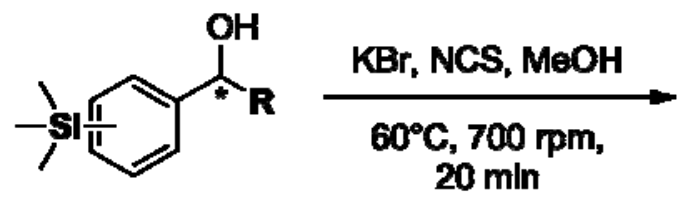

$2 b, c, 0, f$<smiles>[R]C(O)c1ccc(Br)cc1</smiles>

$1 b, c, e, f$

The enantioenriched bromides 1b, 1c, 1e and 1f were submitted to chiral GC and HPLC analysis, and the retention times were compared with those described in the literature [42-45]. Thus, absolute configuration of enantioenriched aryltrimethylsilyl $(S)$-alcohols and $(R)$-acetates were determined by analogy to the results found for the bromophenyl $(S)$-alcohols. The stereochemistry found for the resolved aryltrimethylsilyl chiral alcohols and acetates is in accordance with the Kaslauskas' rule prediction [46].

\section{Experimental}

\subsection{General Methods}

All the enzymes were purchased from the Sigma-Aldrich Chemical Company and stored at $4{ }^{\circ} \mathrm{C}$. All solvents used were HPLC or ACS grade. THF and $\mathrm{Et}_{2} \mathrm{O}$ were distilled from $\mathrm{Na}$ /benzophenone. $\mathrm{CH}_{2} \mathrm{Cl}_{2}$ was distilled from $\mathrm{CaH}_{2}$. Nuclear magnetic resonance (NMR) spectra were recorded on a Varian Gemini 200 or Bruker DPX 300 spectrometer at operating frequencies of 200 and $300 \mathrm{MHz}$ ( $\left.{ }^{1} \mathrm{H}-\mathrm{NMR}\right)$ or 50 and $75 \mathrm{MHz}\left({ }^{13} \mathrm{C}-\mathrm{NMR}\right)$. The ${ }^{1} \mathrm{H}-\mathrm{NMR}$ chemical shifts are reported in ppm relative 
to TMS peak. Data are reported as follows: chemical shift $(\delta)$, multiplicity ( $\mathrm{s}=$ singlet, $\mathrm{d}=$ doublet, $\mathrm{t}=$ triplet, $\mathrm{q}=$ quartet, $\mathrm{m}=$ multiplet), coupling constant $(J)$ in Hertz and integrated intensity. The

${ }^{13} \mathrm{C}$-NMR chemical shifts are reported in ppm relative to $\mathrm{CDCl}_{3}$ signal. Infrared spectra were recorded from $\mathrm{KBr}$ discs on a Bomem Michelson model 101 FTIR spectrometer. Absorption maxima $\left(v_{\max }\right)$ are reported in wavenumbers $\left(\mathrm{cm}^{-1}\right)$. Low-resolution mass spectra were obtained on a GC/MS Shimadzu spectrometer, operating at $70 \mathrm{eV}$. High-resolution mass spectra (HRMS) were acquired using a Bruker Daltonics MicroTOF instrument, operating electrospray ionization (ESI) mode. Gas chromatography (GC) analysis for measurement of enantiomeric excess was obtained using a Shimadzu 17-A Gas Chromatograph, Flame Ionization Detector (FID), and a chiral column Varian CP-Chirasil-DEX CB $\beta$-ciclodextrin $(25 \mathrm{~m} \times 0.32 \mathrm{~mm} \times 0.25 \mu \mathrm{m})$. Temperature of the detector and injector was $250{ }^{\circ} \mathrm{C}$; oven temperature: from $100{ }^{\circ} \mathrm{C}$ to $150{ }^{\circ} \mathrm{C}, 1^{\circ} \mathrm{C} / \mathrm{min}$; flow $=80 \mathrm{kPa}, \mathrm{H}_{2}$ as gas carrier.

\subsection{Synthetic Procedures}

\subsubsection{General Procedure for the Preparation of 1-(Bromophenyl)ethanols 1a-c $[35,47]$}

Ketone (10 mmol, $1.99 \mathrm{~g})$ was added to a $250 \mathrm{~mL}$ round-bottomed flask containing ethanol $(20 \mathrm{~mL})$ cooled at $0{ }^{\circ} \mathrm{C}$, followed by the addition of $\mathrm{NaBH}_{4}(11 \mathrm{mmol}, 0.42 \mathrm{mg})$ in small portions. The mixture was stirred for $30 \mathrm{~min}$ at $0{ }^{\circ} \mathrm{C}$ and for $2.5 \mathrm{~h}$ at room temperature. The ethanol was evaporated under reduced pressure and $\mathrm{H}_{2} \mathrm{O}(20 \mathrm{~mL})$ was added to the organic residue. The mixture was treated with aqueous acid solution $(1 \mathrm{M} \mathrm{HCl})$ until $\mathrm{pH}$ 6, and extracted with $\mathrm{CH}_{2} \mathrm{Cl}_{2}(3 \times 20 \mathrm{~mL})$. Organic phase was dried over anhydrous $\mathrm{MgSO}_{4}$, and the solvent was evaporated under reduced pressure. The crude product was purified by column chromatography using $n$-hexane/ethyl acetate (8:2) as eluent. All spectral data of compounds 1a-c were in agreement with those described in the literature [48].

\subsubsection{General Procedure for the Preparation of 1-(Bromophenyl)propanols 1d-f [49]}

To a $100 \mathrm{~mL}$, two-necked, round-bottom flask fitted with a reflux condenser and containing a suspension of magnesium (15 mmol, $0.36 \mathrm{~g})$ in $\mathrm{Et}_{2} \mathrm{O}(4 \mathrm{~mL})$, a solution of bromoethane (15 mmol, $1.63 \mathrm{~g}, 1.12 \mathrm{~mL})$ in $\mathrm{Et}_{2} \mathrm{O}(12 \mathrm{~mL})$ was added dropwise under $\mathrm{N}_{2}$ atmosphere. The mixture was refluxed for $30 \mathrm{~min}$. Then the solution of ethylmagnesium bromide was cooled to $-5{ }^{\circ} \mathrm{C}$ and a solution of the appropriate brom-benzaldehyde $(10 \mathrm{mmol}, 1.85 \mathrm{~g})$ in $\mathrm{Et}_{2} \mathrm{O}(8 \mathrm{~mL})$ was added dropwise. The mixture was stirred for $1 \mathrm{~h}$ at r.t., poured on ice, and acidified with $6 \mathrm{M} \mathrm{HCl}$. The organic layer was separated, and the aqueous layer was extracted with $\mathrm{Et}_{2} \mathrm{O}(3 \times 5 \mathrm{~mL})$. The organic solutions were combined, washed with $10 \% \mathrm{NaHCO}_{3}$ solution $(2 \times 5 \mathrm{~mL}), \mathrm{H}_{2} \mathrm{O}(2 \times 5 \mathrm{~mL})$, brine $(2 \times 5 \mathrm{~mL})$, and dried over anhydrous $\mathrm{MgSO}_{4}$. The crude product was purified by column chromatography using $n$-hexane/ethyl acetate (9:1) as eluent. All spectral data of the compounds 1d-f were in agreement with those described in the literature [42].

\subsubsection{General Procedure for the Preparation of Aryltrimethylsilyl Chiral Alcohols 2a-f $[11,50]$}

A $50 \mathrm{~mL}$, two-necked, round-bottom flask under $\mathrm{N}_{2}$ atmosphere was charged with a solution of the appropriate alcohol 1a-f $(5 \mathrm{mmol})$ in THF $(15 \mathrm{~mL})$. The mixture was cooled to $-70{ }^{\circ} \mathrm{C}$ and, a solution of $n$-butyllithium (12.5 mmol, $1.6 \mathrm{M}$ in hexanes, $7.80 \mathrm{~mL})$ was added dropwise. The mixture was 
stirred at $-70{ }^{\circ} \mathrm{C}$ for $2 \mathrm{~h}$. Trimethylsilyl chloride (14 mmol, $\left.1.52 \mathrm{~g}, 1.78 \mathrm{~mL}\right)$ was added, and after 30 min at $-70{ }^{\circ} \mathrm{C}$, the solution was allowed to warm to room temperature and stirred overnight. The reaction was quenched by the addition of aqueous acid solution $(1 \mathrm{M} \mathrm{HCl}, 15 \mathrm{~mL})$ and stirred for 1 hour. The organic layer was separated and the aqueous layer extracted with ethyl acetate $(3 \times 10 \mathrm{~mL})$. The combined organic layers were washed with saturated solution of $\mathrm{NaHCO}_{3}(2 \times 25 \mathrm{~mL})$ and brine $(2 \times 25 \mathrm{~mL})$, dried over anhydrous $\mathrm{MgSO}_{4}$ and concentrated in vacuo. The residue was purified by column chromatography using $n$-hexane/ethyl acetate (9:1) as eluent.

1-(2-(Trimethylsilyl)phenyl)ethanol (2a). Yield: $606 \mathrm{mg}(62 \%)$. White solid. ${ }^{1} \mathrm{H}-\mathrm{NMR}(200 \mathrm{MHz}$, $\left.\mathrm{CDCl}_{3}\right) \delta=0.35(\mathrm{~s}, 9 \mathrm{H}), 1.49(\mathrm{~d}, J=6.0 \mathrm{~Hz}, 3 \mathrm{H}), 5.11(\mathrm{q}, J=6.0 \mathrm{~Hz}, 1 \mathrm{H}), 7.23-7.64(\mathrm{~m}, 4 \mathrm{H})$. ${ }^{13} \mathrm{C}-\mathrm{NMR}\left(50 \mathrm{MHz}, \mathrm{CDCl}_{3}\right): \delta=0.85,25.38,69.84,125.32,127.21,130.07,134.42,137.06,151.65$. FT-IR $(\mathrm{KBr}) v \max =3284,3058,2956,1930,1630,1432,1247,1099,1072,1000,848,731 \mathrm{~cm}^{-1}$. LRMS (EI) $m / z(\%)=179(15), 161(100), 145(62), 133(21), 119(8), 104(12), 91(10), 75(33), 59(9)$, 43(49). HRMS (ESI): Calculated for $\mathrm{C}_{11} \mathrm{H}_{18} \mathrm{OSiNa}[\mathrm{M}+\mathrm{Na}]^{+}=217.1025$; found: 217.1018 .

1-(3-(Trimethylsilyl)phenyl)ethanol (2b). Yield: $702 \mathrm{mg}$ (72\%). Colourless oil. ${ }^{1} \mathrm{H}-\mathrm{NMR}(200 \mathrm{MHz}$, $\left.\mathrm{CDCl}_{3}\right) \delta=0.27(\mathrm{~s}, 9 \mathrm{H}), 1.50(\mathrm{~d}, J=6.0 \mathrm{~Hz}, 3 \mathrm{H}), 4.86(\mathrm{q}, J=6.0 \mathrm{~Hz}, 1 \mathrm{H}), 7.30-7.52(\mathrm{~m}, 4 \mathrm{H})$. ${ }^{13} \mathrm{C}-\mathrm{NMR}\left(50 \mathrm{MHz}, \mathrm{CDCl}_{3}\right): \delta=-0.93,25.32,70.84,126.08,128.09,130.46,132.75,141.02,145.05$. FT-IR $(\mathrm{KBr}) v \max =3343,3048,2956,1594,1450,1248,1098,858,837,753 \mathrm{~cm}^{-1}$. LRMS (EI) $\mathrm{m} / z$ $(\%)=194(7)[\mathrm{M}]^{+}, 179(100), 161(33), 145(8), 135(15), 119(10), 104(11), 91(8), 75(54), 59(9), 43(60)$. HRMS (ESI): Calculated for $\mathrm{C}_{11} \mathrm{H}_{18} \mathrm{OSiNa}[\mathrm{M}+\mathrm{Na}]^{+}=217.1025$; found: 217.1015.

1-(4-(Trimethylsilyl)phenyl)ethanol (2c). Yield: $743 \mathrm{mg}(76 \%)$. White waxy solid. ${ }^{1} \mathrm{H}-\mathrm{NMR}(200 \mathrm{MHz}$, $\left.\mathrm{CDCl}_{3}\right) \delta=0.30(\mathrm{~s}, 9 \mathrm{H}), 1.51(\mathrm{~d}, J=6.0 \mathrm{~Hz}, 3 \mathrm{H}), 4.86(\mathrm{q}, J=6.0 \mathrm{~Hz}, 1 \mathrm{H}), 7.37(\mathrm{~d}, J=8.0 \mathrm{~Hz}, 2 \mathrm{H})$, $7.53(\mathrm{~d}, J=8.0 \mathrm{~Hz}, 2 \mathrm{H}) .{ }^{13} \mathrm{C}-\mathrm{NMR}\left(50 \mathrm{MHz}, \mathrm{CDCl}_{3}\right): \delta=-0.94,25.20,70.57,124.96,133.75,139.83$, 146.53. FT-IR $(\mathrm{KBr})$ vmax $=3323,3068,2955,1918,1601,1410,1247,1082,1071,1003,857,822 \mathrm{~cm}^{-1}$. LRMS (EI) $m / z(\%)=194(8)[\mathrm{M}]^{+}, 179(100), 163(6), 151(4), 135(8), 119(7), 105(12), 91(7), 73(23)$, 59(3), 43(38). HRMS (ESI): Calculated for $\mathrm{C}_{11} \mathrm{H}_{18} \mathrm{OSiNa}[\mathrm{M}+\mathrm{Na}]^{+}=217.1025$; found: 217.1019 .

1-(2-(Trimethylsilyl)phenyl)propanol (2d). Yield: $673 \mathrm{mg}(65 \%)$. Colourless oil. ${ }^{1} \mathrm{H}-\mathrm{NMR}(300 \mathrm{MHz}$, $\mathrm{CDCl} 3) \delta=0.34(\mathrm{~s}, 9 \mathrm{H}), 1.01(\mathrm{t}, J=6.0 \mathrm{~Hz}, 3 \mathrm{H}), 1.69-1.88(\mathrm{~m}, 2 \mathrm{H}), 4.83(\mathrm{~m}, 1 \mathrm{H}), 7.23-7.55(\mathrm{~m}, 4 \mathrm{H})$. ${ }^{13} \mathrm{C}-\mathrm{NMR}\left(75 \mathrm{MHz}, \mathrm{CDCl}_{3}\right): \delta=0.96,11.01,32.11,75.22,125.57,127.17,129.94,134.53,137.63$, 150.67. FT-IR (KBr) vmax $=3387,3056,2959,1590,1459,1250,1105,968,838,730 \mathrm{~cm}^{-1}$. LRMS (EI) $m / z(\%)=193(16), 175(87), 163(100), 145(18), 135(12), 117(15), 105(14), 91(12), 75(53)$, 59(94), 45(39). HRMS (ESI): Calculated for $\mathrm{C}_{12} \mathrm{H}_{20} \mathrm{OSiNa}[\mathrm{M}+\mathrm{Na}]^{+}=231.1181$; found: 231.1175.

1-(3-(Trimethylsilyl)phenyl)propanol (2e). Yield: $725 \mathrm{mg}$ (70\%). Colourless oil. ${ }^{1} \mathrm{H}-\mathrm{NMR}$ (300 MHz, $\mathrm{CDCl} 3) \delta=0.27(\mathrm{~s}, 9 \mathrm{H}), 0.92(\mathrm{t}, J=6.0 \mathrm{~Hz}, 3 \mathrm{H}), 1.68-1.86(\mathrm{~m}, 2 \mathrm{H}), 4.55(\mathrm{t}, J=6.0 \mathrm{~Hz}, 1 \mathrm{H}), 7.30-7.47$ (m, 4H). ${ }^{13} \mathrm{C}-\mathrm{NMR}\left(75 \mathrm{MHz}, \mathrm{CDCl}_{3}\right): \delta=-0.94,10.40,32.06,76.38,126.60,127.94,131.03,132.67$, 140.75, 143.92. FT-IR $(\mathrm{KBr}) v \max =3351,3052,2958,1586,1441,1248,1121,860,837,753 \mathrm{~cm}^{-1}$. LRMS (EI) $m / z(\%)=208(4)[\mathrm{M}]^{+}, 193(32), 179(100), 163(10), 145(4), 135(10), 119(7), 105(10)$, 91(9), 73(94), 59(26), 43(31). HRMS (ESI): Calculated for $\mathrm{C}_{12} \mathrm{H}_{20} \mathrm{OSiNa}[\mathrm{M}+\mathrm{Na}]^{+}=231.1181$; found: 231.1171 . 
1-(4-(Trimethylsilyl)phenyl)propanol (2f). Yield: $706 \mathrm{mg}$ (68\%). White solid. ${ }^{1} \mathrm{H}-\mathrm{NMR}(300 \mathrm{MHz}$, $\left.\mathrm{CDCl}_{3}\right) \delta=0.26(\mathrm{~s}, 9 \mathrm{H}), 0.30(\mathrm{t}, J=6.0 \mathrm{~Hz}, 3 \mathrm{H}), 1.70-1.85(\mathrm{~m}, 2 \mathrm{H}), 4.57(\mathrm{t}, J=6.0 \mathrm{~Hz}, 1 \mathrm{H}), 7.31(\mathrm{~d}$, $J=9.0 \mathrm{~Hz}, 2 \mathrm{H}), 7.49(\mathrm{~d}, J=9.0 \mathrm{~Hz}, 2 \mathrm{H}) .{ }^{13} \mathrm{C}-\mathrm{NMR}\left(75 \mathrm{MHz}, \mathrm{CDCl}_{3}\right): \delta=-0.92,10.38,31.97,76.19$, 125.53, 133.64, 139.81, 145.36. FT-IR $(\mathrm{KBr}) v \max =3323,3068,2957,1598,1453,1401,1248$, 1111, 1094, 853, $837 \mathrm{~cm}^{-1}$. LRMS (EI) $\mathrm{m} / z(\%)=208(3)[\mathrm{M}]^{+}, 193(51), 179(100), 163(14), 151(7)$, 135(14), 119(8), 105(11), 91(13), 73(76), 59(8), 43(28). HRMS (ESI): Calculated for $\mathrm{C}_{12} \mathrm{H}_{20} \mathrm{OSiNa}$ $[\mathrm{M}+\mathrm{Na}]^{+}=231.1181$; found: 231.1176 .

\subsubsection{General Procedure for the Preparation of Aryltrimethylsilyl Chiral Acetates 3a-f [51]}

To a $25 \mathrm{~mL}$ round-bottom flask containing a solution of the appropriate aryltrimethylsilyl chiral alcohol $(0.5 \mathrm{mmol})$ in $\mathrm{CH}_{2} \mathrm{Cl}_{2}(5 \mathrm{~mL})$, was added acetic anhydride $(0.6 \mathrm{mmol}, 0.06 \mathrm{~g}, 56.3 \mu \mathrm{L})$, pyridine $(2 \mathrm{mmol}, 0.16 \mathrm{~g}, 161.5 \mu \mathrm{L})$ and DMAP $(0.1 \mathrm{mmol}, 12.2 \mathrm{mg})$, sequentially. The mixture was stirred overnight at r.t. Then the solvent was evaporated under reduced pressure and ethyl acetate $(15 \mathrm{~mL})$ was added to the organic residue. The organic layer was washed with aq. $1 \mathrm{M} \mathrm{CuSO}_{4}(2 \times 10 \mathrm{~mL})$, brine $(2 \times 10 \mathrm{~mL})$, dried over anhydrous $\mathrm{MgSO}_{4}$ and concentrated in vacuo. The residue was purified by column chromatography using $n$-hexane/ethyl acetate (9:1) as eluent.

1-(2-(Trimethylsilyl)phenyl)ethyl acetate (3a). Yield: $112 \mathrm{mg}(95 \%)$. Colourless oil. ${ }^{1} \mathrm{H}-\mathrm{NMR}(200 \mathrm{MHz}$, $\left.\mathrm{CDCl}_{3}\right) \delta=0.36(\mathrm{~s}, 9 \mathrm{H}), 1.50(\mathrm{~d}, J=6.0 \mathrm{~Hz}, 3 \mathrm{H}), 2.06(\mathrm{~s}, 3 \mathrm{H}), 6.06(\mathrm{q}, J=6.0 \mathrm{~Hz}, 1 \mathrm{H}), 7.24-7.55(\mathrm{~m}, 4 \mathrm{H})$.

${ }^{13} \mathrm{C}-\mathrm{NMR}\left(50 \mathrm{MHz}, \mathrm{CDCl}_{3}\right): \delta=0.63,21.61,23.62,72.43,125.97,127.38,129.77,134.48,137.29$, 147.73, 170.37. FT-IR $(\mathrm{KBr}) v \max =3024,2960,1740,1599,1436,1237,1019,1037,838 \mathrm{~cm}^{-1}$. LRMS (EI) $m / z(\%)=221(5), 193(3), 177(3), 161(30), 145(25), 133(8), 117(67), 103(6), 91(3), 75(19), 59(7)$, 43(100). HRMS (ESI): Calculated for $\mathrm{C}_{13} \mathrm{H}_{20} \mathrm{O}_{2} \mathrm{SiNa}[\mathrm{M}+\mathrm{Na}]^{+}=259.1130$; found: 259.1128 .

1-(3-(Trimethylsilyl)phenyl)ethyl acetate (3b). Yield: $115 \mathrm{mg}(98 \%)$. Colourless oil. ${ }^{1} \mathrm{H}-\mathrm{NMR}(200 \mathrm{MHz}$, $\left.\mathrm{CDCl}_{3}\right) \delta=0.27(\mathrm{~s}, 9 \mathrm{H}), 1.53(\mathrm{~d}, J=6.0 \mathrm{~Hz}, 3 \mathrm{H}), 2.07(\mathrm{~s}, 3 \mathrm{H}), 5.85(\mathrm{q}, J=6.0 \mathrm{~Hz}, 1 \mathrm{H}), 7.33-7.48(\mathrm{~m}, 4 \mathrm{H})$. ${ }^{13} \mathrm{C}-\mathrm{NMR}\left(50 \mathrm{MHz}, \mathrm{CDCl}_{3}\right): \delta=-0.95,21.56,22.44,72.70,126.72,128.04,131.15,133.11,140.90$, 140.99, 170.50. FT-IR $(\mathrm{KBr}) v \max =3050,2956,1739,1587,1448,1247,1065,1024,839 \mathrm{~cm}^{-1}$. LRMS (EI) $m / z(\%)=236(4)[\mathrm{M}]^{+}, 221(1), 193(11), 177(4), 161(28), 135(4), 117(30), 103(5), 91(2), 75(33)$, 59(4), 43(100). HRMS (ESI): Calculated for $\mathrm{C}_{13} \mathrm{H}_{20} \mathrm{O}_{2} \mathrm{SiNa}[\mathrm{M}+\mathrm{Na}]^{+}=259.1130$; found: 259.1125 .

1-(4-(Trimethylsilyl)phenyl)ethyl acetate (3c). Yield: $114 \mathrm{mg}(97 \%)$. Colourless oil. ${ }^{1} \mathrm{H}-\mathrm{NMR}(200 \mathrm{MHz}$, $\left.\mathrm{CDCl}_{3}\right) \delta=0.30(\mathrm{~s}, 9 \mathrm{H}), 1.52(\mathrm{~d}, J=6.0 \mathrm{~Hz}, 3 \mathrm{H}), 2.07(\mathrm{~s}, 3 \mathrm{H}), 5.86(\mathrm{q}, J=6.0 \mathrm{~Hz}, 1 \mathrm{H}), 7.32(\mathrm{~d}$, $J=8.0 \mathrm{~Hz}, 2 \mathrm{H}), 7.49(\mathrm{~d}, J=8.0 \mathrm{~Hz}, 2 \mathrm{H}) .{ }^{13} \mathrm{C}-\mathrm{NMR}\left(50 \mathrm{MHz}, \mathrm{CDCl}_{3}\right): \delta=-0.98,21.51,22.29,72.48$, $125.60,133.71,140.31,142.30,170.50$. FT-IR $(\mathrm{KBr}) v \max =3020,2955,1738,1602,1447,1241$, 1063, 1022, $850 \mathrm{~cm}^{-1}$. LRMS (EI) $\mathrm{m} / z(\%)=236(2)[\mathrm{M}]^{+}, 221(7), 194(8), 177(4), 161(14), 151(14)$, 133(4), 119(11), 103(7), 91(4), 75(19), 59(5), 43(100). HRMS (ESI): Calculated for $\mathrm{C}_{13} \mathrm{H}_{20} \mathrm{O}_{2} \mathrm{SiNa}$ $[\mathrm{M}+\mathrm{Na}]^{+}=259.1130$; found: 259.1131 .

1-(2-(Trimethylsilyl)phenyl)propyl acetate (3d). Yield: $121 \mathrm{mg}(97 \%)$. Colourless oil. ${ }^{1} \mathrm{H}-\mathrm{NMR}(300 \mathrm{MHz}$, $\left.\mathrm{CDCl}_{3}\right) \delta=0.38(\mathrm{~s}, 9 \mathrm{H}), 0.96(\mathrm{t}, J=6.0 \mathrm{~Hz}, 3 \mathrm{H}), 1.71-1.91(\mathrm{~m}, 2 \mathrm{H}), 2.07(\mathrm{~s}, 3 \mathrm{H}), 5.93(\mathrm{t}, J=6 \mathrm{~Hz}$, $1 \mathrm{H}), 7.23-7.51(\mathrm{~m}, 4 \mathrm{H}) .{ }^{13} \mathrm{C}-\mathrm{NMR}\left(75 \mathrm{MHz}, \mathrm{CDCl}_{3}\right): \delta=0.78,10.59,21.44,31.16,77.09,125.88$, 
127.23, 129.53, 134.63, 137.61, 147.11, 170.54. FT-IR $(\mathrm{KBr}) v \max =3058,2967,1738,1591,1434$, 1372, 1235, 1085, 1046, $840 \mathrm{~cm}^{-1}$. LRMS (EI) $\mathrm{m} / \mathrm{z}(\%)=235(1), 207(1), 175(4), 163(11), 145(6)$, 135(4), 117(55), 105(4), 91(3), 75(15), 59(25), 43(100). HRMS (ESI): Calculated for $\mathrm{C}_{14} \mathrm{H}_{22} \mathrm{O}_{2} \mathrm{SiNa}$ $[\mathrm{M}+\mathrm{Na}]^{+}=273.1287$; found: 273.1283 .

1-(3-(Trimethylsilyl)phenyl)propyl acetate (3e). Yield: $118 \mathrm{mg}(95 \%)$. Colourless oil. ${ }^{1} \mathrm{H}-\mathrm{NMR}(300 \mathrm{MHz}$, $\left.\mathrm{CDCl}_{3}\right) \delta=0.27(\mathrm{~s}, 9 \mathrm{H}), 0.89(\mathrm{t}, J=6.0 \mathrm{~Hz}, 3 \mathrm{H}), 1.76-1.97(\mathrm{~m}, 2 \mathrm{H}), 2.08(\mathrm{~s}, 3 \mathrm{H}), 5.68(\mathrm{t}, J=6 \mathrm{~Hz}$, 1H), 7.31-7.46 (m, 4H). ${ }^{13} \mathrm{C}-\mathrm{NMR}\left(75 \mathrm{MHz}, \mathrm{CDCl}_{3}\right): \delta=-0.94,10.19,21.46,29.62,77.72,127.13$, 127.93, 131.64, 133.04, 139.88, 140.83, 170.61. FT-IR (KBr) vmax $=3050,2957,1740,1459,1372$, 1237, 1085, 1020, $839 \mathrm{~cm}^{-1}$. LRMS (EI) $\mathrm{m} / z(\%)=250(4)[\mathrm{M}]^{+}, 235(1), 221(3), 207(9), 175(20)$, 163(8), 135(4), 117(34), 105(4), 91(4), 75(32), 59(8), 43(100). HRMS (ESI): Calculated for $\mathrm{C}_{14} \mathrm{H}_{22} \mathrm{O}_{2} \mathrm{SiNa}[\mathrm{M}+\mathrm{Na}]^{+}=273.1287$; found: 273.1288 .

1-(4-(Trimethylsilyl)phenyl)propyl acetate (3f). Yield: $119 \mathrm{mg}(96 \%)$. Colourless oil. ${ }^{1} \mathrm{H}-\mathrm{NMR}(200 \mathrm{MHz}$, $\left.\mathrm{CDCl}_{3}\right) \delta=0.25(\mathrm{~s}, 9 \mathrm{H}), 0.89(\mathrm{t}, J=6.0 \mathrm{~Hz}, 3 \mathrm{H}), 1.73-2.00(\mathrm{~m}, 2 \mathrm{H}), 2.07(\mathrm{~s}, 3 \mathrm{H}), 5.65(\mathrm{t}, J=6 \mathrm{~Hz}$, $1 \mathrm{H}), 7.28(\mathrm{~d}, J=8.0 \mathrm{~Hz}, 2 \mathrm{H}), 7.47(\mathrm{~d}, J=8.0 \mathrm{~Hz}, 2 \mathrm{H}) .{ }^{13} \mathrm{C}-\mathrm{NMR}\left(50 \mathrm{MHz}, \mathrm{CDCl}_{3}\right): \delta=-0.97,10.14$, 21.42, 29.43, 77.54, 126.05, 133.58, 140.17, 141.20, 170.61. FT-IR (KBr) vmax = 3024, 2960, 1740, 1599, 1436, 1237, 1085, 1019, $838 \mathrm{~cm}^{-1}$. LRMS (EI) $\mathrm{m} / z(\%)=250(5)[\mathrm{M}]^{+}, 235(4), 221(8), 208(15)$, 179(23), 165(9), 135(4), 117(33), 105(6), 91(4), 75(27), 59(7), 43(100). HRMS (ESI): Calculated for $\mathrm{C}_{14} \mathrm{H}_{22} \mathrm{O}_{2} \mathrm{SiNa}[\mathrm{M}+\mathrm{Na}]^{+}=273.1287$; found: 273.1282 .

\subsection{Determination of the Enantiomeric Excess (ee)}

The enantiomeric excesses of the aryltrimethylsilyl chiral alcohols 2a-f and esters 3a-f were measured by chiral GC analysis. The analysis was carried out on Varian CP-Chirasil-DEX CB $\beta$-ciclodextrin $(25 \mathrm{~m} \times 0.32 \mathrm{~mm} \times 0.25 \mu \mathrm{m})$. Temperature of the detector and injector was $250{ }^{\circ} \mathrm{C}$; oven temperature: from $100^{\circ} \mathrm{C}$ to $150{ }^{\circ} \mathrm{C}, 1^{\circ} \mathrm{C} / \mathrm{min}$; flow $=80 \mathrm{kPa}, \mathrm{H}_{2}$ as gas carrier.

Retention times $\left(t_{\mathrm{R}}\right)$ :

(2a): $t_{\mathrm{R}}=19.8 \mathrm{~min}$ for $(S)$ and $t_{\mathrm{R}}=20.9 \mathrm{~min}$ for $(R)$;

(2b): $t_{\mathrm{R}}=19.6 \mathrm{~min}$ for $(S)$ and $t_{\mathrm{R}}=20.1 \mathrm{~min}$ for $(R)$;

(2c): $t_{\mathrm{R}}=26.5 \mathrm{~min}$ for $(S)$ and $t_{\mathrm{R}}=25.6 \mathrm{~min}$ for $(R)$;

(2d): $t_{\mathrm{R}}=21.6 \mathrm{~min}$ for $(S)$ and $t_{\mathrm{R}}=22.6 \mathrm{~min}$ for $(R)$;

(2e): $t_{\mathrm{R}}=25.0 \mathrm{~min}$ for $(S)$ and $t_{\mathrm{R}}=24.4 \mathrm{~min}$ for $(R)$;

(2f): $t_{\mathrm{R}}=31.2 \mathrm{~min}$ for $(S)$ and $t_{\mathrm{R}}=30.3 \mathrm{~min}$ for $(R)$;

(3a): $t_{\mathrm{R}}=16.0 \mathrm{~min}$ for $(S)$ and $t_{\mathrm{R}}=16.2 \mathrm{~min}$ for $(R)$;

(3b): $t_{\mathrm{R}}=16.2 \mathrm{~min}$ for $(S)$ and $t_{\mathrm{R}}=16.8 \mathrm{~min}$ for $(R)$;

(3c): $t_{\mathrm{R}}=23.7 \mathrm{~min}$ for $(S)$ and $t_{\mathrm{R}}=25.9 \mathrm{~min}$ for $(R)$;

(3d): $t_{\mathrm{R}}=63.4 \mathrm{~min}$ for $(S)$ and $t_{\mathrm{R}}=63.6 \mathrm{~min}$ for $(R)$ (oven: $50{ }^{\circ} \mathrm{C}$ to $150{ }^{\circ} \mathrm{C}, 1{ }^{\circ} \mathrm{C} / \mathrm{min}$ );

(3e): $t_{\mathrm{R}}=22.0 \mathrm{~min}$ for $(S)$ and $t_{\mathrm{R}}=20.4 \mathrm{~min}$ for $(R)$;

(3f): $t_{\mathrm{R}}=26.3 \mathrm{~min}$ for $(S)$ and $t_{\mathrm{R}}=27.1 \mathrm{~min}$ for $(R)$; 


\subsection{Enzymatic Procedures}

\subsubsection{General Procedure for Small Scale Enzymatic Reactions}

A $1.5 \mathrm{~mL}$ Eppendorf tube $(2 \mathrm{~mL})$ was charged with the appropriate aryltrimethylsilyl chiral alcohol 2a-f $(0.05 \mathrm{mmol})$, hexanes (HPLC grade, $200 \mu \mathrm{L})$, CAL-B (enzyme amount as indicated in Tables 1-3) and vinyl acetate $(2.2$ equiv., $0.11 \mathrm{mmol}, 10 \mu \mathrm{L})$. The reaction mixture was sealed and stirred on a thermomixer $\left(30{ }^{\circ} \mathrm{C}, 700 \mathrm{rpm}\right)$ until the appropriate time. After that, the mixture was filtered and the solvent evaporated under reduced pressure.

\subsubsection{General Procedure for Preparative-Scale Enzymatic Reactions}

A $10 \mathrm{~mL}$ glass tube was charged with the appropriate aryltrimethylsilyl chiral alcohol 2a-f ( $1 \mathrm{mmol}$ ), hexanes (HPLC grade, $4 \mathrm{~mL}$ ), CAL-B (enzyme amount as indicated on Table 4) and vinyl acetate $(2.2 \mathrm{mmol}, 203 \mu \mathrm{L})$. The reaction mixture was sealed and stirred on a thermomixer $\left(30{ }^{\circ} \mathrm{C}\right.$, $700 \mathrm{rpm}$ ) until the appropriate time. After that, the mixture was filtered and the solvent evaporated under reduced pressure. The purification of alcohol $\mathbf{2}$ and acetate $\mathbf{3}$ was performed by column chromatography using $n$-hexane/ethyl acetate (9:1) as eluent.

$(S)-2 b$ : isolated yield $=44 \%$; enantiomeric excess $>99 \% ;[\alpha]_{\mathrm{D}}{ }^{20}=-37.0\left(c=1.0 ; \mathrm{CHCl}_{3}\right)$.

$(R)$-3b: isolated yield $=49 \%$; enantiomeric excess $>99 \% ;[\alpha]_{\mathrm{D}}{ }^{20}=+70.8\left(c=1.0 ; \mathrm{CHCl}_{3}\right)$.

$(S)-2 \mathrm{c}$ : isolated yield $=31 \%$; enantiomeric excess $>99 \% ;[\alpha]_{\mathrm{D}}{ }^{20}=-31.2\left(c=1.0 ; \mathrm{CHCl}_{3}\right)$.

$(R)$-3c: isolated yield $=46 \%$; enantiomeric excess $>99 \% ;[\alpha]_{\mathrm{D}}{ }^{20}=+93.9\left(c=1.0 ; \mathrm{CHCl}_{3}\right)$.

$(S)-2 \mathrm{e}$ : isolated yield $=38 \%$; enantiomeric excess $>99 \% ;[\alpha]_{\mathrm{D}}{ }^{20}=-32.9\left(c=1.0 ; \mathrm{CHCl}_{3}\right)$.

$(R)$-3e: isolated yield $=49 \%$; enantiomeric excess $>99 \% ;[\alpha]_{\mathrm{D}}{ }^{20}=+76.8\left(c=1.0 ; \mathrm{CHCl}_{3}\right)$.

$(S)-2 f$ : isolated yield $=39 \%$; enantiomeric excess $>99 \% ;[\alpha]_{\mathrm{D}}{ }^{20}=-34.1\left(c=1.0 ; \mathrm{CHCl}_{3}\right)$.

$(R)-3 f$ : isolated yield $=34 \%$; enantiomeric excess $>99 \%$; $[\alpha]_{\mathrm{D}}{ }^{20}=+91.3\left(c=1.0 ; \mathrm{CHCl}_{3}\right)$.

\subsection{Determination of the Absolute Configuration}

3.5.1. General Procedure for Transformation of Enantioenriched Aryltrimethylsilyl Chiral Alcohols 2b, 2c, 2e and $\mathbf{2 f}$ to Their Bromide Derivatives [52]

To a solution of the appropriate enantioenriched aryltrimethylsilyl chiral alcohol $(0.05 \mathrm{mmol})$ dissolved in $\mathrm{MeOH}(1.0 \mathrm{~mL})$ was added $\mathrm{KBr}(0.05 \mathrm{mmol}, 6 \mathrm{mg})$ and NCS $(0.05 \mathrm{mmol}, 7 \mathrm{mg})$. The mixture was stirred for $20 \mathrm{~min}$ at $60{ }^{\circ} \mathrm{C}$. The reaction was quenched with $\mathrm{H}_{2} \mathrm{O}(2 \mathrm{~mL})$ and extracted with $\mathrm{CH}_{2} \mathrm{Cl}_{2}(2 \times 5 \mathrm{~mL})$. The organic layer was washed with brine $(2 \times 2 \mathrm{~mL})$, dried over anhydrous $\mathrm{MgSO}_{4}$ and concentrated in vacuo. The residue was purified by column chromatography using $n$-hexane/ethyl acetate (9:1) as eluent.

3.5.2. Determination of Absolute Configuration of Enantioenriched Aryltrimethylsilyl Chiral Alcohols 2b, 2c, 2e and $2 \mathbf{f}$

The enantioenriched alcohols $\mathbf{1 b}, \mathbf{1 c}, \mathbf{1 e}$ and $\mathbf{1 f}$ obtained from the bromodesilylation reactions (section 3.4.1) were submitted to chiral GC and HPLC analysis, and the values found for retention 
times were in agreement with enantiopure samples and those described in the literature for enantioenriched compounds [42-45]. The absolute configuration of compounds $\mathbf{2 b}, \mathbf{2} \mathbf{c}, \mathbf{2 e}$ and $\mathbf{2 f}$ were attributed by analogy of those found to its bromide derivatives.

\section{Conclusions}

An extensive study of lipase-catalyzed kinetic resolution of aryltrimethylsilyl chiral alcohols through an enantioselective transesterification was described. The best lipase source found for kinetic resolution of these silicon-containing compounds was Pseudomonas cepacia (Amano PS-C II). Different enzyme/substrate ratios were evaluated and a very small amount of lipase proved to be satisfactory for the kinetic resolution in most cases. The kinetic resolution of $o$-substituted phenyl chiral alcohols did not occur under the conditions evaluated. The reason for this surprisingly results is still opened for further studies, but a possible explanation is that a pseudo-pentacoordinated species generated by a non-bonded $\mathrm{Si}^{\cdots} \mathrm{O}$ attraction, should create a steric hindrance that made the kinetic resolution more difficult to occur. On the other hand, perfect kinetic resolutions were achieved for the $m$ - and $p$-substituted phenyl chiral alcohols, in which $(S)$-alcohols and $(R)$-acetates were obtained in high yields (up to 49\%) and excellent enantiomeric excesses (>99\%).

\section{Acknowledgments}

The authors want to thank FAPESP (State of São Paulo Research Foundation), CNPq (National Counsel of Technological and Scientific Development) and CAPES (Coordination for the Improvement of Higher Level -or Education-Personnel) for their fellowship and financial support.

\section{References and Notes}

1. Colvin, E.W. Silicon Reagents in Organic Synthesis, 1st ed.; Academic Press: San Diego, CA, USA, 1988; pp. 7-137.

2. Patai, S.; Rappoport, Z. The Chemistry of Organic Silicon Compounds, 1st ed.; Wiley: New York, NY, USA, 1998; Volume 2, pp. 1667-1793.

3. Gilman, H.; Dunn, G.E. Relationships between analgous organic compounds of silicon and carbon. Chem. Rev. 1953, 52, 77-115.

4. Burkhard, C.A.; Rochow, E.G.; Booth, H.S.; Hartt, J. The present state of organosilicon chemistry. Chem. Rev. 1947, 41, 97-149.

5. Yoshida, H.; Sugiura, S.; Kunai, A. Facile synthesis of $N$-alkyl- $N$ '-arylimidazolium salts via addition of imidazoles to arynes. Org. Lett. 2002, 4, 2767-2769.

6. Dockendorff, C.; Sahli, S.; Olsen, M.; Milhau, L.; Lautens, M. Synthesis of dihydronaphthalenes via aryne Diels-Alder reactions: Scope and diastereoselectivity. J. Am. Chem. Soc. 2005, 127, 15028-15029.

7. Liu, Z.; Larock, R.C. Highly efficient route to fused polycyclic aromatics via palladium-catalyzed aryne annulation by aryl halides. J. Org. Chem. 2007, 72, 223-232.

8. Xie, C.; Liu, L.; Zhang, Y.; Xu, P. Copper-catalyzed Alkyne-aryne and alkyne-alkene-aryne coupling reactions. Org. Lett. 2008, 10, 2393-2396. 
9. Gebara, K.S.; Casagrande, G.A.; Raminelli, C. An efficient fluoride-mediated $O$-arylation of sterically hindered halophenols with silylaryl triflates under mild reaction conditions. Tetrahedron Lett. 2011, 52, 2849-2852.

10. McAusland, D.; Seo, S.; Pintori, D.G.; Finlayson, J.; Greaney, M.F. The benzyne Fischer-indole reaction. Org. Lett. 2011, 13, 3667-3669.

11. Brenzovich, W.E.; Brazeau, J.-F.; Toste, F.D. Gold-catalyzed oxidative coupling reactions with aryltrimethylsilanes. Org. Lett. 2010, 12, 4728-4731.

12. Ball, L.T.; Green, M.; Lloyd-Jones, G.C.; Russell, C.A. Arylsilanes: Application to gold-catalyzed oxyarylation of alkenes. Org. Lett. 2010, 12, 4724-4727.

13. Suzawa, K.; Ueno, M.; Wheatley, A.E.H.; Kondo, Y. Phosphazene base-promoted functionalization of aryltrimethylsilanes. Chem. Commun. 2006, 4850-4852.

14. Nakao, Y.; Imanaka, H.; Sahoo, A.K.; Yada, A.; Hiyama, T. Alkenyl- and aryl[2(hydroxymethyl)phenyl]dimethylsilanes: An entry to tetraorganosilicon reagents for the siliconbased cross-coupling reaction. J. Am. Chem. Soc. 2005, 127, 6952-6953.

15. Nakao, Y.; Imanaka, H.; Chen, J.; Yada, A.; Hiyama, T. Synthesis and cross-coupling reaction of alkenyl[(2-hydroxymethyl)phenyl]dimethylsilanes. J. Organomet. Chem. 2007, 692, 585-603.

16. Chen, J.; Tanaka, M.; Sahoo, A.K.; Takeda, M.; Yada, A.; Nakao, Y.; Hiyama, T. Synthesis of biaryls and oligoarenes using aryl[2-(hydroxymethyl)phenyl]dimethylsilanes. Bull. Chem. Soc. Jpn. 2010, 83, 554-569.

17. Nakao, Y.; Takeda, M.; Matsumoto, T.; Hiyama, T. Cross-coupling reactions through the intramolecular activation of alkyl(triorgano)silanes. Angew. Chem. Int. Ed. 2010, 49, 4447-4450.

18. Denmark, S.E. The interplay of invention, discovery, development, and application in organic synthetic methodology: A case study. J. Org. Chem. 2009, 74, 2915-2927.

19. Rauf, W.; Brown, J.M. Catalytic amide-mediated methyl transfer from silanes to alkenes in fujiwara-moritani oxidative coupling. Angew. Chem. Int. Ed. 2008, 47, 4228-4230.

20. Tacke, R.; Brakmann, S.; Wuttke, F. Stereoselective microbial reduction of racemic acetyl $(t-$ butyl)methylphenylsilane by Trigonopsis variabilis (DSM 70714) and Corynebacterium dioxydans (ATCC 21766). J. Organomet. Chem. 1991, 403, 29-41.

21. Yamanaka, H.; Kawamoto, T.; Tanaka, A. Efficient preparation of optically active p-trimethylsilylphenylalanine by using cell-free extract of Blastobacter sp. A17p-4. J. Ferment. Bioeng. 1997, 84, 181-184.

22. Zani, P. Biotransformations of organosilicon compounds: enantioselective reduction of acyl silanes by means of baker's yeast. J. Mol. Catal. B: Enzym. 2001, 11, 279-285.

23. Li, N.; Zong, M.-H.; Peng, H.-S.; Wu, H.-C.; Liu, C. $(R)$-Oxynitrilase-catalyzed synthesis of (R)-2-trimethylsilyl-2-hydroxyl-ethylcyanide. J. Mol. Catal. B: Enzym. 2003, 22, 7-12.

24. Maraite, A.; Ansorge-Schumacher, M. B.; Ganchegui, B.; Leitner, W.; Grogan, G. On the biocatalytic cleavage of silicon-oxygen bonds: A substrate structural approach to investigating the cleavage of protecting group silyl ethers by serine-triad hydrolases. J. Mol. Catal. B: Enzym. 2009, 56, 24-28.

25. Frampton, M.B.; Simionescu, R.; Dudding, T.; Zelisko, P.M. The enzymatic cleavage of Si-O bonds: A kinetic analysis of the biocatalyzed hydrolysis of phenyltrimethoxysilane. J. Mol. Catal. B: Enzym. 2010, 66, 105-112. 
26. Bassindale, A.R.; Brandstadt, K.F.; Lane, T.H.; Taylor, P.G. Enzyme-catalysed siloxane bond formation. J. Inorg. Biochem. 2003, 96, 401-406.

27. Abbate, V.; Bassindale, A.R.; Brandstadt, K.F.; Lawson, R.; Taylor, P.G. Enzyme mediated silicon-oxygen bond formation; the use of Rhizopus oryzae lipase, lysozyme and phytase under mild conditions. Dalton Trans. 2010, 39, 9361-9368.

28. Abbate, V.; Bassindale, A.R.; Brandstadt, K.F.; Taylor, P.G. A large scale enzyme screen in the search for new methods of silicon-oxygen bond formation. J. Inog. Biochem. 2011, 105, 268-275.

29. Djerourou, A.-H.; Blanco, L. Synthesis of optically active 2-sila-1,3-propanediols derivatives by enzymatic transesterification. Tetrahedron Lett. 1991, 32, 6325-6326.

30. Fukui, T.; Kawamoto, T.; Tanaka, A. Enzymatic preparation of optically active silylmethanol derivatives having a stereogenic silicon atom by hydrolase-catalyzed enantioselective esterification. Tetrahedron: Asymmetry 1994, 5, 73-82.

31. Burgess, K.; Jennings, L.D. Enantioselective esterifications of unsaturated alcohols mediated by a lipase prepared from Pseudomonas sp. J. Am. Chem. Soc. 1991, 113, 6129-6139.

32. Allevi, P.; Ciuffreda, P.; Anastasia, M. Lipase catalysed resolution of $(R)$ - and $(S)$-1-trimethylsilyl1-alkyn-3-ols-Useful intermediates for the synthesis of optically active $\gamma$-lactones. Tetrahedron: Asymmetry 1997, 8, 93-99.

33. Ratnayake, A.S.; Hemscheidt, T. Olefin cross-metathesis as a tool in natural product degradation. The stereochemistry of (+)-Falcarindiol. Org. Lett. 2002, 4, 4667-4669.

34. Brawn, R.A.; Panek, J.S. Preparation and use of enantioenriched allenylsilanes for the stereoselective synthesis of homopropargylic ethers. Org. Lett. 2007, 9, 2689-2692.

35. Andrade, L.H.; Omori, A.T.; Porto, A.L.M.; Comasseto, J.V. Asymmetric synthesis of arylselenoalcohols by means of the reduction of organoseleno acetophenones by whole fungal cells. J. Mol. Catal. B: Enzym. 2004, 29, 47-54.

36. Bianchi, D.; Battistel, E.; Bosetti, A.; Cesti, P.; Fekete, Z. Effects of chemical modification on stereoselectivity of Pseudomonas cepacia lipase. Tetrahedron: Asymmetry 1993, 4, 777-782.

37. Ignatyev, I.S. Intramolecular coordination of silicon in silyl formates: Spectroscopic evidence confirmed by ab initio calculations. J. Mol. Struct. 1991, 245, 139-145.

38. Tamao, K.; Asahara, M.; Sun, G.-R.; Kawachi, A. Synthesis, structure, and reactivity of 1, $\omega$-bis(pseudo-pentacoordinated) 1, $\omega$-difluoro-oligosilanes bearing 8-(dimethylamino)-1naphthyl groups. J. Organomet. Chem. 1999, 574, 193-205.

39. Tamao, K.; Asahara, M.; Saeki, T.; Toshimitsu, A. Enhanced nucleophilicity of ambiphilic silylene and silylenoid bearing 8-(dimethylamino)-1-naphthyl group. J. Organomet. Chem. 2000, 600, 118-123.

40. Pongor, G.; Kolos, Z.; Szalay, R.; Knausz, D. Pseudo-pentacoordination in silylcarbamates: structure-based prediction of silylating power. J. Mol. Struct. (THEOCHEM) 2005, 714, 87-97.

41. Szalay, R.; Pongor, G.; Harmat, V.; Böcskei, Z.; Knausz, D. Surprisingly great difference in reactivity depending upon the ring size: Solvolysis and molecular structure study of some $\mathrm{N}$-trimethylsilylated cyclic ureas. J. Organomet. Chem. 2005, 690, 1498-1506.

42. Solís, A.; García, S.; Pérez, H.I.; Manjarrez, N.; Luna, H. Screening of liver acetone powders in the resolution of 1-phenylethanols and 1-phenylpropanols derivatives. Tetrahedron: Asymmetry 2008, 19, 549-553. 
43. Salvia, N.A.; Chattopadhyay, S. Asymmetric reduction of halo-substituted arylalkanones with Rhizopus arrhizus. Tetrahedron: Asymmetry 2008, 19, 1992-1997.

44. Machado, L.L.; Lemos, T.L.G.; de Mattos, M.C.; de Oliveira, M.C.F.; de Gonzalo, G.; Gotor-Fernández, V.; Gotor, V. Immobilized Manihot esculenta preparation as a novel biocatalyst in the enantioselective acetylation of racemic alcohols. Tetrahedron: Asymmetry 2008, 19, 1419-1424.

45. Araújo, L.S.; Kagohara, E.; Garcia, T.P.; Pellizari, V.H.; Leandro, H.; Andrade, L.H. Screening of microorganisms producing cold-active oxidoreductases to be applied in enantioselective alcohol oxidation. An antarctic survey. Mar. Drugs 2011, 9, 889-905.

46. Kazlauskas, R.J.; Weissfloch, A.N.E.; Rappaport, A.T.; Cuccia, L.A. A rule to predict which enantiomer of a secondary alcohol reacts faster in reactions catalyzed by cholesterol esterase, lipase from Pseudomonas cepacia, and lipase from Candida rugosa. J. Org. Chem. 1991, 56, 2656-2665.

47. Andrade, L.H.; Polak, R.; Porto, A.L.M.; Schoenlein-Crusius, I.H.; Comasseto, J.V. Application of bioreduction by microorganisms in the enantioselective synthesis of alpha-substituted-1phenylethanols. Lett. Org. Chem. 2006, 3, 613-618.

48. Nakamura, K.; Matsuda, T. Asymmetric reduction of ketones by the acetone powder of Geotrichum candidum. J. Org. Chem. 1998, 63, 8957-8964.

49. Zaidlewicz, M.; Wolan, A. Syntheses with organoboranes. XIII. Synthesis of $\omega-(4-$ bromophenyl)alkanoic acids and their borylation. J. Organomet. Chem. 2002, 657, 129-135.

50. Achmatowicz, B.; Raubo, P.; Wicha, J. Synthesis of four stereoisomeric tetrose derivatives from propargyl alcohol. One-carbon homologation of vinylsilanes via alpha, beta-epoxy silanes. J. Org. Chem. 1992, 57, 6593-6598.

51. Demasi, M.; Felicio, A.L.; Pacheco, A.O.; Leite, H.G.; Lima, C.; Andrade, L.H. Studies on terrein as a new class of proteasome inhibitors. J. Braz. Chem. Soc. 2010, 21, 299-305.

52. Wilbur, D.S.; Stone, W.E.; Anderson, K.W. Regiospecific incorporation of bromine and iodine into phenols using (trimethylsilyl)phenol derivatives. J. Org. Chem. 1983, 48, 1542-1544.

Sample Availability: Not available.

(C) 2011 by the authors; license MDPI, Basel, Switzerland. This article is an open access article distributed under the terms and conditions of the Creative Commons Attribution license (http://creativecommons.org/licenses/by/3.0/). 